\section{Grafting as a promising technique for popularizing marigold cultivation in bacterial wilt sick soils in humid tropics of Kerala, India}

\author{
U. Jeevan ${ }^{1, *}$, U. Sreelatha ${ }^{1}$, C. Narayanankutty ${ }^{2}$, \\ M. S. Parvathi ${ }^{3}$ and T. V. Anupama ${ }^{1}$ \\ ${ }^{1}$ Department of Floriculture and Landscaping, College of Agriculture, \\ Kerala Agricultural University, Thrissur 680 656, India \\ ${ }^{2}$ Agricultural Research Station, Mannuthy, \\ Kerala Agricultural University, Thrissur 680 656, India \\ ${ }^{3}$ Department of Plant Physiology, College of Agriculture, \\ Kerala Agricultural University, Thrissur 680 656, India
}

Studies on grafting nine susceptible genotypes including five $F_{1}$ hybrids and four varieties of African marigold was conducted by using two bacterial wilt resistant marigold lines (M-1 and $\mathrm{M}-2$ ) as rootstocks. It was evident from the present study that the $F_{1}$ hybrids recorded better survival of grafts compared to varieties of African marigold. The greatest survival of grafts was recorded in hybrid Bhagwati grafted on M-1 rootstock $(60 \%)$, which was on par with Bhagwati grafted on M-2 (54\%), Maria 91 grafted on M-1 $(54 \%)$ and Maria 91 grafted on M-2 $(50 \%)$. Irrespective of the scion genotypes, $M-1$ as rootstock recorded better graft survival $(34.22 \%)$ compared to a survival of $25.56 \%$ in case of M-2. And, irrespective of the rootstock genotypes, the highest survival was recorded in Bhagwati (57\%), on par with Maria 91 (52\%).

Keywords: Bacterial wilt, cleft grafting, marigold, rootstock.

DUE to its versatile nature, ease in cultivation and multipurpose uses, African marigold (Tagetes erecta) is a popular commercial loose flower crop in India. In addition to its ornamental use, the carotenoids extracted from the flowers are used in various industries such as pharmaceuticals, food supplements, feed additives, food colourants and cosmetics. The flower crop is gaining momentum in Kerala state, with farmers coming forward targeting the festival seasons, than relying on neighbouring states. However, bacterial wilt is a serious problem for successful cultivation of marigold under humid tropics of Kerala. Being a soil borne pathogen, it has critical comprehensive management limitations. Grafting, an alternate approach to impart tolerance/resistance to various biotic and abiotic stresses, is being commercially exploited in solanaceous crops and cucurbits to manage bacterial wilt disease ${ }^{1}$. Complete control of bacterial wilt has been possible through grafting in solanaceous crops ${ }^{2}$. In this context, a grafting approach to achieve bacterial wilt resistance in marigold was attempted for the first

*For correspondence. (e-mail: jeevan.horti@gmail.com) time in Kerala Agricultural University, Thrissur, using varieties/accessions suitable for the state. Complete resistance to bacterial wilt has been reported in two African marigold genotypes, viz. M-1 (ref. 3) and M-2 (ref. 4). Using M-1 as the rootstock, cleft grafting was standardized as the best method in African marigold ${ }^{5}$.

To study the response of different genotypes to grafting, nine genotypes highly susceptible to bacterial wilt ${ }^{4}$, viz. five hybrids (Suvarna Orange, Suvarna Yellow, Sakura 031, Maria 91, Bhagwati) and four varieties (Pusa Narangi Gainda, Pusa Basanti Gainda, Double Orange and Double Yellow) were grafted on the two wilt resistant genotypes, M-1 and M-2. Thirty-five day old scions were cleft grafted onto 45-day old rootstocks and supported with grafting clips. Grafted plants were kept in a mist chamber for healing of graft unions for 7 days and then acclimatized in a naturally ventilated greenhouse for 7 days before transplanting to plots. The design was factorial complete randomized design (FCRD) with 18 treatments which were replicated thrice.

Grafting success was dependent on the genotypes of rootstock, scion and their interactions (Table 1). It was evident from the data that $F_{1}$ hybrids recorded better graft survival compared to varieties of African marigold. The highest per cent survival of grafts was recorded in the hybrid Bhagwati grafted on M-1 rootstock (60\%), which was on par with Bhagwati grafted on M-2 (54\%), Maria 91 grafted on M-1 (54\%) and Maria 91 grafted on M-2 $(50 \%)$. Irrespective of the scion genotype, M-1 as rootstock recorded better graft survival $(34.22 \%)$ compared to a survival of $25.56 \%$ in case of M-2 rootstock. The genotype of scion also had high influence on graft survival; wherein the highest survival was recorded in Bhagwati $(57 \%)$ which was on par with Maria 91 (52\%), irrespective of the genotype of rootstocks.

Number of days for the establishment of graft union varied with scion genotypes and the interaction between scion and rootstock types; but not dependent on the genotype of rootstock (Table 2). Earliest graft union was observed in Maria 91 (4.0 days) grafted on M-1 and M-2, which was similar to Bhagwati grafted on M-1 (4.0 days); and Suvarna Orange and Suvarna Yellow grafted on M-1, both with 4.5 days for establishment of graft union. Thus, irrespective of the genotype of rootstock, Maria 91 and Bhagwati recorded earliest graft union compared to other genotypes. $F_{1}$ hybrids took less days for graft union success and also exhibited better graft survival compared to other varieties of African marigold used in our study. This might be attributed to their hybrid vigour that might have facilitated faster callus differentiation along the cut surfaces and formation of vascular connections between scion and rootstock.

The success rate of grafting depends on well-developed connections between vascular bundles of both scion and rootstock. To know the compatibility of the scion and rootstock, we studied the stem anatomy at grafting stage. 
Table 1. Percent survival of grafts in Tagetes erecta. L

\begin{tabular}{|c|c|c|c|c|c|c|c|c|c|c|}
\hline \multirow[b]{3}{*}{$\begin{array}{l}\text { Root stocks } \\
\text { (Factor A) }\end{array}$} & \multicolumn{10}{|c|}{ Scion genotypes (Factor B) } \\
\hline & \multicolumn{5}{|c|}{ Hybrids } & \multicolumn{5}{|c|}{ Varieties } \\
\hline & $\begin{array}{c}\text { Suvarna } \\
\text { Orange }\end{array}$ & $\begin{array}{l}\text { Suvarna } \\
\text { Yellow }\end{array}$ & Sakura 031 & Maria 91 & Bhagwati & $\begin{array}{c}\text { Pusa } \\
\text { Narangi } \\
\text { Gainda }\end{array}$ & $\begin{array}{c}\text { Pusa } \\
\text { Basanti } \\
\text { Gainda }\end{array}$ & $\begin{array}{l}\text { Double } \\
\text { Orange }\end{array}$ & $\begin{array}{l}\text { Double } \\
\text { Yellow }\end{array}$ & Mean A \\
\hline M-1 & 44 & 40 & 42 & 54 & 60 & 30 & 26 & 6 & 6 & 34.22 \\
\hline M-2 & 42 & 34 & 44 & 50 & 54 & 2 & 4 & 0 & 0 & 25.55 \\
\hline Mean B & 43 & 37 & 43 & 52 & 57 & 15 & 6.5 & 3 & 3 & 28.83 \\
\hline Factors & & $\mathrm{CD}(0.01)$ & $\mathrm{SEm} \pm$ & & & & & & & \\
\hline Factor (A) & & 3.64 & 1.21 & & & & & & & \\
\hline Factor (B) & & 7.74 & 2.57 & & & & & & & \\
\hline Factor $(A \times B)$ & & 10.94 & 3.63 & & & & & & & \\
\hline
\end{tabular}

Table 2. Days to graft union in Tagetes erecta $\mathrm{L}$.

\begin{tabular}{|c|c|c|c|c|c|c|c|c|c|c|}
\hline \multirow[b]{3}{*}{$\begin{array}{l}\text { Root stocks } \\
\text { (Factor A) }\end{array}$} & \multicolumn{10}{|c|}{ Scion genotypes (Factor B) } \\
\hline & \multicolumn{5}{|c|}{ Hybrids } & \multicolumn{5}{|c|}{ Varieties } \\
\hline & $\begin{array}{l}\text { Suvarna } \\
\text { Orange }\end{array}$ & $\begin{array}{l}\text { Suvarna } \\
\text { Yellow }\end{array}$ & Sakura 031 & Maria 91 & Bhagwati & $\begin{array}{c}\text { Pusa } \\
\text { Narangi } \\
\text { Gainda }\end{array}$ & $\begin{array}{c}\text { Pusa } \\
\text { Basanti } \\
\text { Gainda }\end{array}$ & $\begin{array}{l}\text { Double } \\
\text { Orange }\end{array}$ & $\begin{array}{l}\text { Double } \\
\text { Yellow }\end{array}$ & Mean A \\
\hline M-1 & 4.5 & 4.5 & 5.0 & 4.0 & 4.0 & 6.0 & 5.5 & 5.0 & 6.0 & 4.94 \\
\hline M-2 & 5.0 & 5.0 & 5.0 & 4.0 & 5.0 & 5.0 & 5.5 & 5.5 & 6.0 & 5.05 \\
\hline Mean B & 4.75 & 4.75 & 5.0 & 4.0 & 4.5 & 5.5 & 5.5 & 5.25 & 6.0 & \\
\hline Factors & & $\mathrm{CD}(0.01)$ & $\mathrm{SEm} \pm$ & & & & & & & \\
\hline Factor (A) & & $\mathrm{N}$ & 0.07 & & & & & & & \\
\hline Factor (B) & & 0.50 & 0.16 & & & & & & & \\
\hline Factor $(\mathrm{A} \times \mathrm{B})$ & & 0.70 & 0.23 & & & & & & & \\
\hline
\end{tabular}

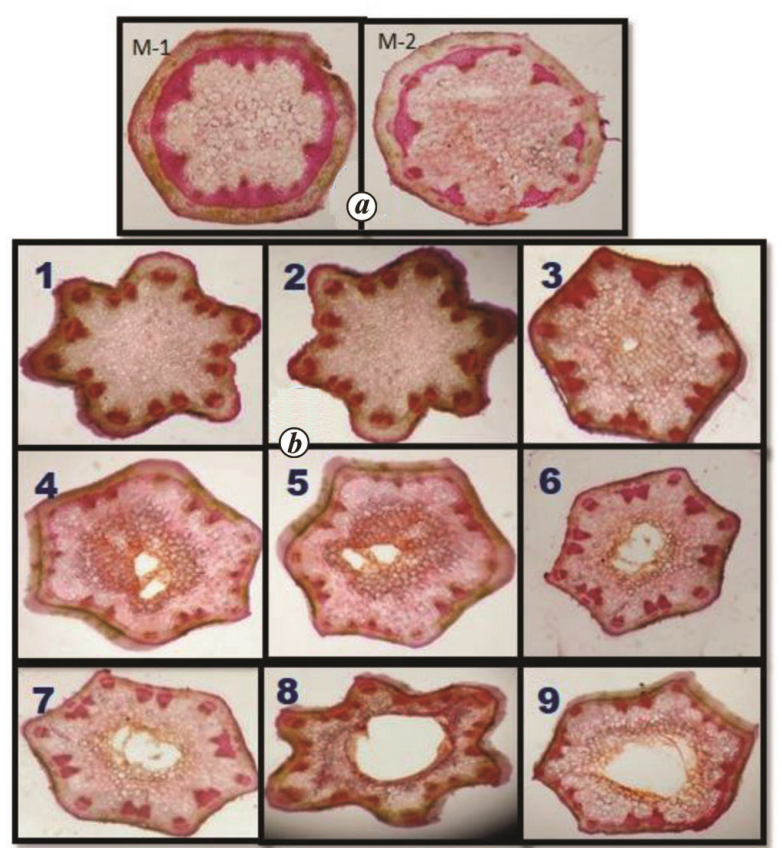

Figure 1. Cross-sections of stems at grafting stage. $\boldsymbol{a}$, Rootstocks: M-1 and M-2; b, Scions: (1) Bhagwati; (2) Maria 91; (3) Suvarna Orange; (4) Suvarna Yellow; (5) Sakura-031; (6) Pusa Basanti Gainda; (7) Pusa Narangi Gainda; (8) Double Orange; (9) Double Yellow.
The reason for poor graft survival in marigold varieties was attributed to defective vascular union at graft interfaces revealed by stem anatomical examination at the stage of grafting (Figure 1). The stem cross-sections of marigold varieties displayed anatomical flaws in the form of a large central hollow portion, which might have contributed to poor vascular connection and improper graft union in them when compared to hybrids. It was also clear that the stems of $F_{1}$ hybrids, particularly Bhagwati and Maria 91 (Figure $1 b$ ) had comparatively more intact central cortex, which might have resulted in their better graft success, mediated by the establishment of early vascular connections between the rootstock and scion. The anatomical compatibility between rootstock and scion is a determining factor in successful graft union and it has been reported that anatomical flaws in either the rootstock or scion adversely affects the grafting success in Pinus engelmanni ${ }^{6}$. Hollow hypocotyl has also been reported as a cause for poor graft survival in melons ${ }^{7}$. The formation of necrotic layer in response to wound repair and proliferation of cells of rootstock and scion is a critical stage prior to callus formation ${ }^{8}$. De-differentiation of the cells and re-differentiation of callus tissue, followed by rapid vascular connection between rootstock and scion is a 


\section{RESEARCH COMMUNICATIONS}

requisite for graft success ${ }^{9}$. There have been similar differential responses among the scion genotypes of Capsicum annuum $^{10}$.

In order to assess the graft efficiency, successfully grafted marigold plants were planted in a bacterial wilt sick plot along with non-grafted marigold plants (Figure $2 b$ ). Grafted plants did not exhibit bacterial wilt symptoms whereas the non-grafted plants started wilting 40-45 days after transplanting (Figure $2 d$ ). Resistance potentiality of the rootstock prospectively inhibits the pathogen spread to the scion, thereby protecting the susceptible type of scion from invasion of wilt causing pathogen. The exact mechanism of tolerance/resistance can be ascertained by targeted studies to determine the mobile signals/metabolites that could possibly be translocated across successful graft unions. This might also vary on the basis of the extent of establishment of anatomically correct vascular connections. There have been reports on transmission of nucleic acids, proteins and critical metabolites involved in graft wound response and repair, and subsequent tolerance potential of the $\operatorname{scion}^{11,12}$. We had earlier reported that the resistance to bacterial wilt in the tolerant marigold rootstocks was positively correlated with flavonoid content in leaves and petals ${ }^{4}$. It will be worthwhile to examine the successful grafts for differential translocation of similar metabolites from tolerant rootstock(s) to susceptible scion(s) across the graft interface, by means of comparative metabolic analysis as has been attempted in recent studies ${ }^{13}$. Breeding and transgrafting $^{14}$ (utilizing genetically engineered rootstocks or scions) approaches using the promising leads obtained
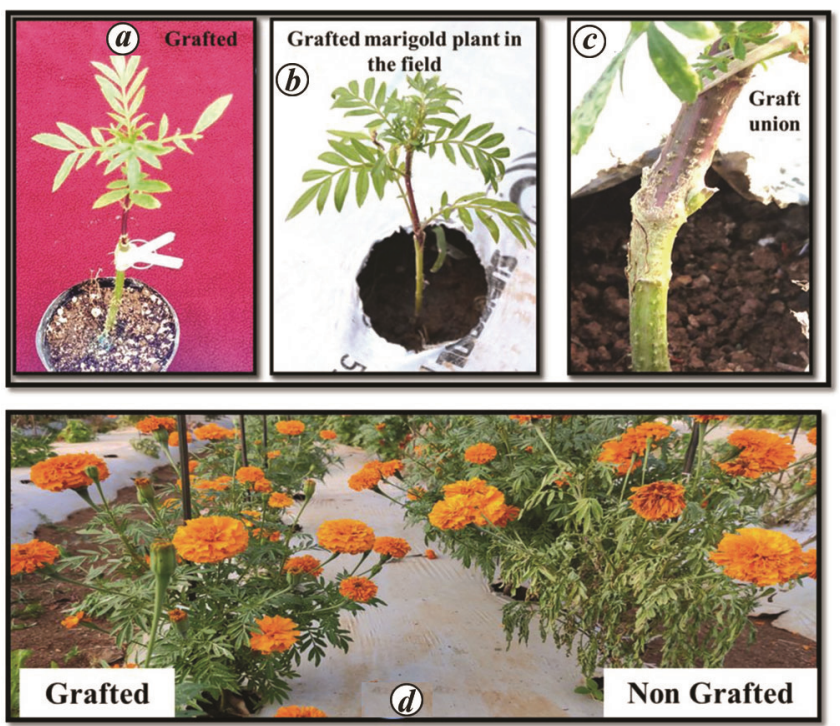

Figure 2. Field level performance of grafted and non-grafted plants under bacterial sick plot. $\boldsymbol{a}$, Grafted marigold plant at transplanting stage; $\boldsymbol{b}$, Grafted marigold plant in the field; $\boldsymbol{c}$, Graft union; $\boldsymbol{d}$, Grafted plant showing resistance in comparison to non-grafted plant in a wilt sick plot under polythene mulch cultivation. from such studies can be channelized to extend the utility of grafting as a potential tool in crop improvement for bacterial wilt resistance.

1. Kumbar, S., Rootstock evaluation and grafting studies in brinjal (Solanum melongena L.). M.Sc. (Hort.) thesis, Kerala Agricultural University, Thrissur, 2019, p. 109.

2. Narayanankutty, C., Sreelatha, U. and Jaikumaran, U., Grafting to combat soil-borne diseases in vegetables. Indian Hortic., 2015, 60(6), 9-10.

3. Umesh, C., Sreelatha, U., Kurian, P. S. and Narayanankutty, C., Evaluation of African marigold (Targets erecta L.) genotypes for yield and resistance to bacterial wilt pathogen, Ralstonia solanacearum. J. Trop. Agric., 2018, 56(1), 86-91.

4. Jeevan, U., Sreelatha, U., Kurian, P. S., Anupama, T. V. and Parvathi, M. S., Assessment of resistance against bacterial wilt in marigold genotypes under humid tropics. J. Trop. Agric., 2019, 57(2), 152-159.

5. Baburaj, A., Sreelatha, U., Anupama, T. V. and Narayanankutty, C., Standardisation of grafting techniques in African marigold (Tagetes erecta L.). J. Trop. Agric., 2019, 56(2), 176-178.

6. Pérez-Luna, A., Prieto-Ruíz, J. Á., López-Upton, J., CarrilloParra, A., Wehenkel, C., Chávez-Simental, J. A. and HernándezDíaz, J. C., Some factors involved in the success of side veneer grafting of Pinus engelmannii Carr. Forests, 2019, 10(2), 112115.

7. Guan, W. and Zhao, X., Techniques for melon grafting. 2019; https://edis.ifas.ufl.edu. HS1257.

8. Akhila, A. N. and George, S. T., Standardization of grafting in bitter gourd (Momordica charantia L.). J. Trop. Agric., 2018, 55(2), 167-174.

9. Tamilselvi, N. A. and Pugalendhi, L., Graft compatibility and anatomical studies of bitter gourd (Momordica charantia L.) scions with cucurbitaceous rootstocks. Int. J. Curr. Microbiol. Appl. Sci., 2017, 6(2), 1801-1810.

10. Soltan, M. M., Elaidy, F. A., Scheerens, J. C. and Kleinhenz, M. D., Grafting, scion and rootstock effects on survival rate, vegetative growth and fruit yield of high tunnel-grown grafted pepper (Capsicum annum L.) plants. Adv. Crop. Sci. Tech., 2017, 5(312), 2 .

11. Liu, Y. F. et al., Grafting helps improve photosynthesis and carbohydrate metabolism in leaves of muskmelon. Int. J. Biol. Sci., 2011, 7(8), 1161-1170.

12. Spanò, R., Ferrara, M., Gallitelli, D. and Mascia, T., The role of grafting in the resistance of tomato to viruses. Plants, 2020, 9(8), 1042.

13. Aslam, A. et al., Comparative analysis of primary metabolites and transcriptome changes between ungrafted and pumpkin-grafted watermelon during fruit development. Peer J., 2020, 8, e8259.

14. Haroldsen, V. M. et al., Mobility of transgenic nucleic acids and proteins within grafted rootstocks for agricultural improvement. Front. Plant Sci., 2012, 3, 39

ACKNOWLEDGEMENTS. We thank Prof. E. V. Anoop, College of Forestry and Prof. Haseena Bhaskar, College of Agriculture, for providing the laboratory facilities for anatomical work and hi-tech horticultural centre for grafting work.

Received 13 November 2020; revised accepted 5 April 2021

doi: $10.18520 / \mathrm{cs} / \mathrm{v} 120 / \mathrm{i} 9 / 1517-1519$ 